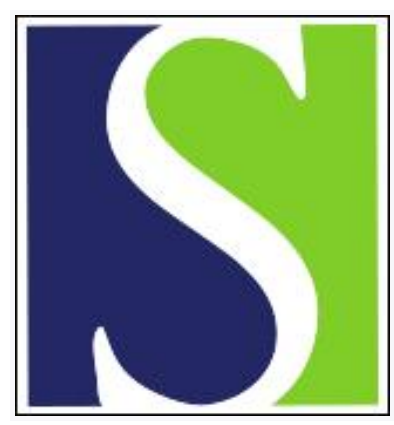

Scand J Work Environ Health 2013;39(2):212-216

https://doi.org/10.5271/sjweh.3317

Published online: 17 Aug 2012, Issue date: 01 Mar 2013

Occupational health services in selected International Commission on Occupational Health (ICOH) member countries by Rantanen J, Lehtinen S, lavicoli S

Affiliation: International Commission on Occupational Health (ICOH), jorma.h.rantanen@gmail.com

Key terms: capacity building; coverage; human resources; ICOH; infrastructure; International Commission on Occupational Health; legal basis; occupational health service; priority; services

This article in PubMed: www.ncbi.nlm.nih.gov/pubmed/22903148 


\title{
Occupational health services in selected International Commission on Occupational Health (ICOH) member countries
}

\author{
by Jorma Rantanen, MD, PhD, ${ }^{1,2}$ Suvi Lehtinen, MSc Econ, ${ }^{1,3}$ Sergio lavicoli, MD, PhD ${ }^{1}$
}

\begin{abstract}
Rantanen J, Lehtinen S, lavicoli S. Occupational health services in selected International Commission on Occupational Health (ICOH) member countries. Scand J Work Environ Health. 2013;39(2):212-216. doi:10.5271/sjweh.3317

Objectives International organizations have encouraged countries to organize occupational health services (OHS) for all working people. This study surveyed how that objective has been achieved in a sample of International Commission on Occupational Health (ICOH) member countries from all continents.
\end{abstract}

Method A structured questionnaire was sent to ICOH national secretaries in 61 countries. The survey focused on (i) policies and strategies; (ii) systems, institutions, and infrastructures; (iii) contents and activities; (iv) human and other resources; (v) financing; and (v) future priorities in the development of national OHS systems.

Results Of 47 respondents, $70 \%$ had drawn up a policy and strategy for OHS and $79 \%$ had a national institute of occupational health or safety. The calculated coverage of workers was 19\% among the respondent countries. Sixty percent of respondent countries used multiple channels for service provision and $70 \%$ provided mixed contents of OHS with preventive and curative services. Almost all (94\%) reported availability of multidisciplinary experts, but not in sufficient numbers. OHS is financed through combined employer plus insurance financing in $62 \%$ of respondents and through employer financing only in $38 \%$. The countries identified well the needs for future development of OHS.

Conclusions In spite of documented policies for OHS, only slightly over one third of the surveyed countries had organized OHS for more than $50 \%$ of workers. The vast majority of workers of the world are underserved due to four gaps in OHS: implementation, coverage, content, and capacity.

Key terms capacity building; coverage; human resources; infrastructure; legal basis; priority; services.

The International Labour Organization (ILO) and the World Health Organization (WHO) have called on member countries to strengthen occupational health services (OHS) to better respond to the needs of health and work ability of their working populations (1-5).

The purpose of the present study was to survey International Commission on Occupational Health (ICOH) member countries on the current status of national OHS systems in view of the objectives and standards set by the aforementioned international organizations.

\section{Methods}

A questionnaire of 20 questions was developed by utilizing the previous occupational health surveys (6-8) for various target groups in OHS. The questions covered six main domains covering (i) normative basis; (ii) OHS system and infrastructures; (iii) substantive orientation and content of OHS; (iv) human resources for OHS; (v) finances for OHS; and (vi) future priorities for development of the national OHS system (tables 1 and 2).

\footnotetext{
1 International Commission on Occupational Health (ICOH).

2 Board, University of Jyväskylä, Jyväskylä, Finland.

3 International Affairs, Finnish Institute of Occupational Health, Helsinki Finland.

4 INAIL, Italian Workers' Compensation Authority, Department of Occupational Medicine (formerly ISPESL National Institute for Occupational Safety and Prevention), Rome, Italy 
Table 1. Responses to survey questions [MoH=Ministry of Health; MoL=Ministry of Labor; $\mathrm{PH}=$ public health; $\mathrm{PHC}=$ primary health care].

\begin{tabular}{|c|c|c|}
\hline \multirow[t]{2}{*}{ Activity } & \multicolumn{2}{|c|}{ Countries replying yes } \\
\hline & $\mathrm{N}$ & $\%$ \\
\hline \multicolumn{3}{|l|}{ Policy \& strategy } \\
\hline $\begin{array}{l}\text { No. } 155 \\
\text { No. } 161 \\
\text { No. } 187\end{array}$ & $\begin{array}{l}23 \\
18 \\
11\end{array}$ & $\begin{array}{l}49 \\
38 \\
23\end{array}$ \\
\hline National policy for $\mathrm{OHS}$ available & 33 & 70 \\
\hline \multicolumn{3}{|l|}{ Institutions and infrastructures } \\
\hline \multicolumn{3}{|l|}{ Governance } \\
\hline Joint MoH-MoL & 25 & 53 \\
\hline $\mathrm{MoL}$ & 14 & 30 \\
\hline $\mathrm{MoH}$ & 8 & 17 \\
\hline $\begin{array}{l}\text { National institute for occupational } \\
\text { health \& safety }\end{array}$ & 37 & 79 \\
\hline \multicolumn{3}{|l|}{ Service provision model } \\
\hline Big industry in-plant service & 42 & 89 \\
\hline Group service & 30 & 64 \\
\hline PHC units or other PH service & 30 & 64 \\
\hline Hospital polyclinics & 20 & 43 \\
\hline Other & 20 & 43 \\
\hline \multicolumn{3}{|l|}{ Professional association } \\
\hline Occupational health physicians & 35 & 75 \\
\hline Occupational hygienists & 24 & 51 \\
\hline Ergonomists & 24 & 51 \\
\hline Safety engineers & 28 & 60 \\
\hline Occupational health nurses & 19 & 40 \\
\hline Occupational psychologists & 13 & 28 \\
\hline \multicolumn{3}{|l|}{ Content of services } \\
\hline Preventive only & 13 & 28 \\
\hline Curative only & 0 & 0 \\
\hline Mixed preventive \& curative & 34 & 72 \\
\hline \multicolumn{3}{|l|}{ Human resources } \\
\hline \multicolumn{3}{|l|}{ Training of experts } \\
\hline Specialty in occupational medicine & 41 & 87 \\
\hline Occupational health nursing & 23 & 49 \\
\hline Occupational hygiene & 24 & 51 \\
\hline \multicolumn{3}{|l|}{ Financing } \\
\hline Employers only & 18 & 38 \\
\hline Insurance & 1 & 2 \\
\hline Combination of employers \& insurance & 28 & 60 \\
\hline
\end{tabular}

Table 2. Responses to survey questions concerning future priorities for development of occupational health services (OHS).

\begin{tabular}{lcc}
\hline Priorities & $\begin{array}{c}\text { Number of } \\
\text { proposals in the } \\
\text { priority group }\end{array}$ & $\begin{array}{c}\text { \% of all 234 } \\
\text { proposals }\end{array}$ \\
\hline $\begin{array}{l}\text { Development of OHS system } \\
\text { and infrastructures }\end{array}$ & 50 & 21 \\
Substantive content & 43 & 18 \\
Organizations and institutions & 37 & 16 \\
Capacity building & 37 & 16 \\
Others (multiple) & 67 & 29 \\
\hline
\end{tabular}

The survey covered $61 \mathrm{ICOH}$ national secretaries with good information on occupational health in their respective countries. Replies were obtained from 47 countries worldwide. Of those who responded, $80 \%$ were affiliated with well-established national organizations, national institutes of occupational health, universities, ministries, or national associations of occupational health. The remaining $20 \%$ came from various sectors of work life.

\section{Results}

\section{Representativeness of the study}

The overall response rate was satisfactory ( $77 \%$ out of 61 countries). The respondent countries have a total of 2.1 billion economically active workers, approximately two-thirds of the total global labor force (4). The highest response rates (75-100\%) were recorded from industrialized countries, but also the rates for developing countries (eg, from Africa) were good (over 60\%).

\section{Policy and strategy}

In line with the ILO recommendation, $70 \%$ of respondents have an OHS policy adopted in most cases at the highest political level (table 1). The majority of the respondent countries stipulate, through law, the obligation of employers to organize OHS to the workers. In some countries, the public sector is responsible for OHS provision.

\section{Institutions and infrastructures}

In 37 countries ( $79 \%$ of respondents), the lead development institution for OHS is the national institute of occupational health, institute of occupational health and

Table 3. Human resources for occupational health services.

\begin{tabular}{lcccr}
\hline Available expert categories & $\begin{array}{c}\text { Available ex- } \\
\text { pert catego- } \\
\text { ries (number } \\
\text { of countries) }\end{array}$ & $\begin{array}{c}\text { Countries } \\
\text { reporting } \\
\text { numbers } \\
\text { of experts }\end{array}$ & $\begin{array}{c}\text { Total } \\
\text { numbers } \\
\text { reported }\end{array}$ \\
\cline { 2 - 4 } & $\mathrm{N}$ & $\%$ & & \\
\hline Occupational health physicians & 47 & 100 & 23 & 67000 \\
Occupational health nurses & 36 & 77 & 16 & 61244 \\
Occupational hygienists & 38 & 81 & 15 & 5505 \\
Ergonomists & 27 & 57 & 11 & 3759 \\
Safety engineers & 41 & 87 & 14 & 43851 \\
Occupational psychologists & 23 & 49 & 6 & 1333 \\
Total number of reported experts & & & & 182692 \\
\hline
\end{tabular}




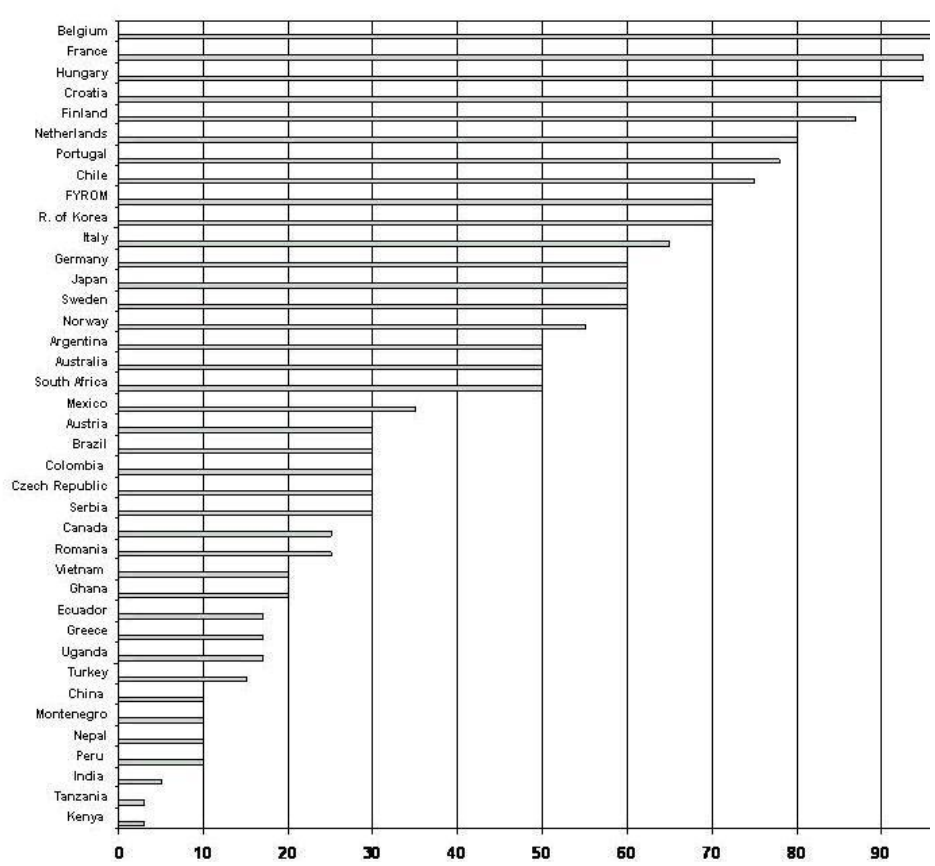

Figure 1. Estimated coverage of $\mathrm{OHS}$ as percentage of employed population reported from 39 countries safety, government authority, or university department (table 1). In some countries (eg, Croatia), the responsibility is shared among several institutions.

\section{Content of services}

In 34 respondent countries ( $72 \%$ ), the OHS provided both preventive and curative services, and in 13 countries $(28 \%)$ preventive services only. The multidisciplinary content of services was common; over $85 \%$ of respondents reported a total of 10 different activities for OHS, including surveillance of work environment and workers' health, risk assessment, health education and information, diagnosis of occupational diseases, and prevention of accidents. The provision of such content requires multidisciplinary OHS staff; $94 \%$ of respondents use $\geq 3$ expert categories in OHS.

\section{Human resources}

Qualitative information on the availability of various expert categories was obtained from most of the responding countries, but only less than half were able to provide numbers in various expert categories (tables 1 and 3 ).

\section{Coverage}

Coverage of OHS as a percentage of the total employed population with services varied widely between $3-97 \%$. More than half of the workforce was covered in 15 countries (38\% of the 39 respondents) (figure 1). Low coverage figures were found in developing countries and large emerging economies. OHS serve approximately 346 million workers in the 39 countries, which provided coverage data, giving an average coverage of $19 \%$ of their total employed population of 1.8 billion. With only a few exceptions, the coverage is insufficient and the gap is seen particularly in small enterprises, among the self-employed, and in agriculture and the informal sector. On average, $81 \%$ of the total working population in the surveyed countries do not have access to services; the respective global estimate is $85-90 \%$ (10).

\section{Financing}

In $62 \%$ of respondent countries "combined financing" (employer and insurance) was applied; in 38\% the "employer-only" model was used (table 1). Thailand finances Basic Occupational Health Services (BOHS) from public sources, Croatia has a specific insurance for OHS, and Finland reimburses $50-60 \%$ of costs of OHS from social insurance to the employer.

\section{Future priorities for development of $\mathrm{OHS}$}

A total of 44 countries (97\%) identified 234 priority development items (table 2): (i) OHS systems (50 items); (ii) substantive content (43); (iii) organizations and institutions (37); (iv) capacity building (37); (v) information systems (20); (vi) legislation (19); (vii) research (19); (viii) financing systems (6); and (ix) others (3). 


\section{Discussion}

Key informant surveys have been widely used in research of health service systems (11). The feasibility of ICOH national secretaries as key informants on OHS in their countries was good. The response rate was reasonable (77\%), and respondents represent roughly $90 \%$ of the total ICOH membership, employing $66 \%$ of the world's total workforce. More accurate quantitative information needs development of national information and statistics systems on OHS.

The replies indicate that the use of ILO instruments as policy guidance is wider than ratification only. Most of the countries, however, have failed in the system-wide implementation of strategies, programs, and international and national instruments ("implementation gap"). In spite of the available national policies and programs, the majority of the workers do not have access to OHS in two-thirds of the respondent countries.

National institutes of occupational health or safety were available in the majority $(79 \%)$ of the countries, but services at the workplace level were less developed. The "coverage gap" was most common in the high-risk sectors, such as small enterprises and agriculture.

There is a shortage of occupational health experts in the world of work ("capacity gap"). To achieve a global density of OHP for the total economically active population [equalling the density calculated for a sample of employed population in 23 countries (with adequate data on numbers of experts) in this survey (1/8155)] would need 312800 more OHP. International organizations have proposed the BOHS and primary health care approaches as solutions to reduce the gap, and there are experiments ongoing in several countries (12-17).

According to the ILO guidance, the OHS should provide surveillance of the work environment and workers' health, risk assessment, prevention of occupational injuries and diseases, first aid, curative care, maintenance of work ability, health promotion and education, and workplace development services (ie, comprehensive $\mathrm{OHS}$ ). The absolute numbers of various expert categories, however, are so limited that the multidisciplinary services are possible only in a few countries. Thus the "content gap" is prevalent.

The combined financing and the employer-only models fit well to the organized sectors of work life. Most of the workers in the coverage gap are employed in less organized settings with high risks, often without any social protection and insurance, and a formal employment contract. Organizing funding for such sectors needs public interventions either through direct government action or through public social insurance.

The low coverage of OHS is often explained by limited financial resources and in interest to ensure economic competitiveness. The financial loss resulting from occupational accidents and diseases, however, is estimated to be $4-5.9 \%$ of GDP (18-19), corresponding to about half of the total health budgets of the countries. The World Economic Forum competitiveness index (20) correlates well with the OHS coverage $(\mathrm{r}=0.52723, \mathrm{t}=3.7228, \mathrm{P}<0.001)$, thus suggesting that the growing coverage does not negatively affect the competitiveness of the countries.

The priorities for future developments aligned well with the identified needs (eg, strengthening of prerequisites, infrastructures, capacities, and content of OHS). There is a greater need for the implementation of the international instruments, national policies, strategies, laws and programs rather than the generation of new instruments. This may reflect the identification of the existing gaps among the responding countries.

\section{Acknowledgements}

The following national respondents to the questionnaire survey are sincerely acknowledged: Argentina - Cristina Pantano; Australia - Wai-On Phoon; Austria - Robert Winker; Belarus - Ilya Veyalkin; Belgium - Simon Bulterys; Bosnia Herzegovina - Nurka Pranjic; Brazil - Jose Carneiro; Canada - Louis Patry; Chile - Veronica Herrera-Moreno; China - Zhijun Zhou; Colombia - Julietta Rodriguez Guzman; Croatia - Jadranka Mustajbegovic, Vlasta Deckovic-Vukres; Czech Republic Daniela Pelclova, M Cikrt, M Tucek, P Urban; Ecuador - Homero Harari; Finland - Ari Kaukiainen, Riitta Sauni, Timo Leino; France - Janine Bigaignon-Fanchette with collaboration of ANSES; FYR Macedonia - Jovanka Karadzinska-Bislimovska; Germany - Hans-Martin Hasselhorn; Ghana - Edith Clarke, Frederick Ohene-Mensah; Greece - Theodore Bazas, Konstantinos Petinis, Alkinoi Krikella; Hungary - Eva Ruzsas; India - S. Sivaramakrishnan; Italy - Leonardo Soleo, Fabio Boccuni, Sergio Iavicoli; Japan - Seichi Horie; Kenya - Irene Karanja; Lebanon - Rima Habib; Lithuania - Vilija Malinauskiene; Luxembourg - Nicole Majery; Mexico - Elia Enriquez; Montenegro - Ljiljana Kezunovic; Nepal - Sunil Kumar Joshi; Norway - Arve Lie, Merete Bugge; Peru - Raul Gomero; Poland - Marek Jakubowski; Portugal - Álvaro Durão; Republic of Korea - Hyoung-Ryoul Kim, SeHoon Lee; Romania - Liliana Rapas; Serbia - Martin Popevic; South Africa - Charles Roos; Sweden - Håkan Westberg; Tanzania - Joshua Matiko, Akwilina Kayumba, Vera Ngowi; Thailand - Rachneekorn Chomsuan; The Netherlands - Monique Frings-Dresen; Turkey - Yucel Demiral, Alp Ergor, Hakan Baydur; Uganda - Yusuf Katula, Christine Haklura, Deogratias Sekimpi, Miti Ronaldley, Nsubuga Mangasi, Barbra Clara Khayongo; USA - Robert Orford; Vietnam - Nguyen Bich Diep. 


\section{References}

1. ILO. Convention No. 161 concerning Occupational Health Services. Geneva 1985. http://www.ilo.org/ilolex/english/ convdisp1.htm. Accessed 31 January 2012.

2. ILO Global Strategy on Occupational Safety and Health: Conclusions. ILO Geneva 2003. p20. http://www.ilo.org/ safework/info/publications/WCMS_107535/lang--en/index. $\mathrm{htm}$. Accessed 31 January 2012.

3. ILO. Convention No. 187 concerning the Promotional Framework for Occupational Safety and Health. Geneva 2006. http://www.ilo.org/ilolex/english/convdisp1.htm. Accessed 31 January 2012

4. World Health Organization. WHO Global Strategy on Occupational Health for All. The Way to Health at Work. Geneva 1995. WHO/OCH/95.1. p68. http://www.who.int/ occupational_health/globstrategy/en/. Accessed 31 January 2012.

5. World Health Organization. WHA Resolution WHA60.26. Global Plan of Action on Workers' Health 2008-2017. Geneva 2007. http://www.who.int/occupational_health/WHO health_assembly_en_web.pdf. Accessed 15 January 2012.

6. Ivanov I. GPA implementation in the European region: Baseline Situation Results from the 2008 WHO country survey. In: Implementation of the WHO Global Plan of Action of Workers' Health in the European Region. The National Focal Points for Workers' Health, 22-23.9.2008. Report. Regional Office for Europe, Copenhagen: WHO 2009. p60.

7. Rantanen J. Occupational health systems in South-East Europe. Copenhagen: WHO Regional Office for Europe. 2012 (in press).

8. Occupational health services: an overview. Rantanen J, editor. Copenhagen: WHO Regional Publications. European Series No. 26. 1990. p48.

9. ILO Labour Statistics. ILO Laborsta 2008 and 2010. http:// laborsta.ilo.org/ (accessed 15 January 2012).

10. Fedotov I. Occupational health services as a key element of national occupational safety and health systems. SJWEH Supplements 2005;1:16-8.

11. WHO Description of the Key Informant Survey. http://www. who.int/responsiveness/surveys/KIS_2001_Methodology. pdf (accessed 2 February 2012).

12. Rantanen J. Basic Occupational Health Services. Edited by S. Lehtinen. Helsinki: Finnish Institute of Occupational Health 2007. p24. http://www.ttl.fi/en/publications/Electronic
publications/Documents/BOHS3Edition28Sept2007_3_.pdf (accessed on 31 January 2012).

13. Arasi DS, R Ayyappan R, Jayachandran P, Thangavel G, Yamini R, Balakrishnan K. Creation of basic occupational health services for health care workers of public health schemes in Tamil Nadu, India. Sri Ramachandra Medical College and Research Institute, Porur, Chennai, Tamil Nadu, India and WHO Country Office for India. Chennai 2009, p122.

14. Bislimovska-Karadzinska J, Minov J, Basanovska V, AgaiDemjaha T, Mijakoski D, Stoleski S. How to maintain the health and work ability of unemployed. Proceedings of the International Forum on Occupational Health and Safety. Finnish Institute of Occupational Health, Helsinki 2012:168-70.

15. Stoleski S, Karadzinska-Bislimovska J, Minov J, Mijakoski D. Current needs and future development in Macedonian rural health policy. Proceedings of the International Forum on Occupational Health and Safety. Finnish Institute of Occupational Health, Helsinki 2012:171-3.

16. Siriruttanapruk S. Integrating Occupational Health Services into Public Health Systems: A Model Developed with Thailand's Primary Care Units. Ministry of Public Health, Thailand. International Labour Office. Informal Economy, Poverty and Employment. Thailand Series Number 2, 2006.

17. Tu NTH, Anh LM. Occupational health services in Vietnam. Asian-Pacific Newsletter on Occupational Health and Safety 2009;16:33-7.

18. ILO Introductory Report: Global Trends and Challenges on Occupational Safety and Health. XIX World Congress on Safety and Health at Work. Istanbul Turkey, 11-15 September 2011. http://www.ilo.org/wcmsp5/groups/public/--ed_protect/---protrav/---safework/documents/publication/ wcms_162662.pdf (accessed on 5 February 2012).

19. The Cost of Work-related Injury and Illness for Australian Employers, Workers and the Community: 2005-06. Government of Australia. Safety Compensation Council March 2009. Commonwealth of Australia 2009 http://safeworkaustralia. gov.au/AboutSafeWorkAustralia/WhatWeDo/Publications/ Documents/178/CostsofWorkRelatedInjuryAndDisease Mar2009.pdf (accessed on 5 February 2012).

20. Schwab K, editor. The Global Competitiveness Report 2010 2011. Geneva, Switzerland: World Economic Forum, 2010. http://www.weforum.org/reports/global-competitivenessreport-2011-2012 (accessed 8 February 2012).

Received for publication: 16 February 2012 